\title{
Statistical Analysis on the Effect of the Utilization of Mineral Resources on the Environmental Impact in China
}

\author{
Wenqi Zhu ${ }^{1,2}$, Kangkang Zhang ${ }^{1,2, *} \mathbb{C}$, Deyi Xu ${ }^{1,2}{ }^{\mathbb{D}}$, Ziyuan Liu ${ }^{1}$ and Jingke Gao ${ }^{1}$ \\ 1 School of Economics and Management, China University of Geosciences, Wuhan 430074, China; \\ zwq@cug.edu.cn (W.Z.); xdy@cug.edu.cn (D.X.); liuziyuan@cug.edu.cn (Z.L.); Gaojingke2021@163.com (J.G.) \\ 2 Research Center of Resource and Environment Economics, China University of Geosciences, \\ Wuhan 430074, China \\ * Correspondence: zkk@cug.edu.cn
}

Citation: Zhu, W.; Zhang, K.; Xu, D.; Liu, Z.; Gao, J. Statistical Analysis on the Effect of the Utilization of Mineral Resources on the Environmental Impact in China. Sustainability 2021, 13, 8462. https://doi.org/10.3390/ su13158462

Academic Editor: Yoshiki Shimomura

Received: 8 June 2021

Accepted: 27 July 2021

Published: 29 July 2021

Publisher's Note: MDPI stays neutral with regard to jurisdictional claims in published maps and institutional affiliations.

Copyright: (c) 2021 by the authors. Licensee MDPI, Basel, Switzerland. This article is an open access article distributed under the terms and conditions of the Creative Commons Attribution (CC BY) license (https:// creativecommons.org/licenses/by/ $4.0 /)$.

\begin{abstract}
Based on the spatial econometric model, this paper mainly studies the impact of the utilization of mineral resources on environmental pollution and the impact of environmental regulation on the utilization of mineral resources in 30 provincial regions from 2003 to 2016, and analyzes the impact mechanism of heterogeneity and synergy. The results show that the utilization of mineral resources intensifies the degree of environmental pollution and the degree of economic spatial agglomeration, while environmental regulation can effectively restrain the utilization of mineral resources in the region and the near adjacent areas. Through the analysis results of synergistic mechanism, it can be seen that the improvement of industrial structure alleviates the impact of the utilization of mineral resources on environmental pollution and the restraining effect of environmental regulation on it. The improvement of technological progress has improved the environmental pollution caused by the utilization of mineral resources in this area, but intensified the environmental pollution degree of the utilization of mineral resources in neighboring areas. In the current technological level, the neighboring areas will consume more mineral resources to meet a certain demand, thus aggravating the environmental pollution of the utilization of mineral resources in the neighboring areas. The enhanced intensity of government management significantly improves the pollution control efficiency of environmental regulation on the utilization of mineral resources.
\end{abstract}

Keywords: environmental regulation; utilization of mineral resources; environmental pollution; spatial econometric model

\section{Introduction}

Mineral resources are the material basis of human existence and development, and economic and social development is closely related to the production and utilization of mineral resources. The acceleration of economic growth has brought with it challenges, including the depletion of natural resources, problems related to globalization and environmental degradation [1]. Over the past 40 years of reform and opening up, China has made great achievements in economic and social development, and its development miracle cannot be achieved without the strong support and guarantee of mineral resources. However, while mineral resources promote economic development, they also bring serious environmental pollution, which greatly threatens human health and the living environment [2] and has become one of the biggest challenges facing human beings [3]. Mineral resources and the ecological environment are the basis on which human beings live. The process of coordinated development of the exploitation and utilization of mineral resources and ecological environment is a dynamic evolutionary process of open complex system involving "nature-society-economy". In the whole industrial chain from mining, smelting to process and manufacturing, mineral resources are always accompanied by the impact on the ecological environment and its interaction [4]. Therefore, the exploitation and utilization of mineral resources and environmental protection are not necessarily contradictory 
bodies, and mineral resources and environment have a complex relationship of mutual influence and restriction [5,6]. The exploitation and utilization of mineral resources is a large system integrated with the construction of the life community of mountains, rivers, forests, fields, lakes and grass. The efficient and green exploitation and utilization of mineral resources can promote ecological environmental protection and ecological civilization construction. The Ministry of Natural Resources issued the Suggestions on Several Matters Concerning Promoting the Reform of Mineral Resources Management on 31 December 2019, which pointed out that the reform of mineral resources management should be comprehensively promoted, and the decisive role of the market in allocating resources should be fully played and the role of the government should be better played. Therefore, it is clear that the development and utilization of mineral resources influences the ecological environment. Thus, it is important to research the effect of mineral resources exploitation, as well as the utilization of the ecological environment, its protection and related regulations, in order to realize coordinated, green development.

With the deepening of the concept of ecological protection and countries' attention to the ecological environment, governments of various countries have imposed strict restrictions on the utilization of mineral resources. Environmental regulations, in turn, also have had a significant impact on the exploitation of mineral resources. Environmental regulation is the act of protecting the natural environment for the benefit of nature and human beings through laws, regulations, conventions or initiatives at the government, organization or individual level. Different types of environmental regulations have different effects on the exploitation of mineral resources. Among them, command-type environmental regulation and market-type environmental regulation are the important factors affecting the utilization of mineral resources, which restrict the environmental damage of mining operations [7] and play a growing role and influence on resource procurement and environmental sustainability [8]. Some scholars also believe that strict enforcement of laws and regulations on mineral resources by national institutions is conducive to the sustainable exploitation of mineral resources [9]. Lange and Redlinger [10] analyzed whether stricter environmental regulations could hinder resource development. However, environmental regulations, such as conventions, initiatives and public opinions reached between governments of various countries, have relatively weak influence on the utilization of mineral resources of enterprises due to their weak constraints. As China's natural resource management system and related functions have undergone major changes, green development in the new era has been continuously promoted, especially the concept of "clear water and green mountains are gold and silver mountains" and the implementation of the withdrawal policy of mining rights in protected areas. Ecological and environmental regulations have become more restrictive to the utilization of mineral resources. Relevant departments urgently require that technological innovation, mechanism innovation [11], management innovation [12,13], scientific assessment of the impact of stricter ecological and environmental regulations on the development and utilization of mineral resources, exploration of the balance between economic development [14], resource development and utilization, and ecological and environmental protection [15], suit the national conditions of China's mineral resources development and utilization, and that ecological environmental protection and coordinated development be implemented. This requirement has become a key problem to be solved urgently in the comprehensive management of natural resources in the new era.

The harmonious development relationship between the utilization of mineral resources and the ecological environment is the premise of the harmonious coexistence between man and nature [16-18]. Scholars at home and abroad have done a lot of work on the ecological and environmental impact of the utilization of mineral resources [19-23]. Among them, Kesler et al. [24] defined the connotation of the environmental effect of the exploitation and utilization of mineral resources and established the basic framework of theoretical analysis of the environmental effect of the exploitation and utilization of mineral resources. Kang and Stam [25] constructed a quantitative model of environmental effect factor weight, providing a basic framework for quantitative assessment of the en- 
vironmental impact of the exploitation and utilization of mineral resources. Besides this, Sanmiquel et al. [26] and Väizene et al. [27] also used the environmental impact system assessment method to measure the surface structure, climate change, water pollution and land-use change caused by the exploitation and utilization of coal and oil shale minerals. Based on the definition of rare mineral resources, Yang et al. [28] used the Environmental Priority Strategy Methodology (EPS) to evaluate the environmental impact of 22 rare minerals in six categories during their life cycle. These studies are mainly on the mineral exploration, mineral exploitation, mining investment, mining taxes and fees, and mining land access, and analyze the impact of the exploitation and utilization of mineral resources on the ecology, as well as the restrictions of the ecological environment on the exploitation and utilization of mineral resources. Although the utilization of mineral resources can bring the impetus of economic development, with economic development entering a better level, scholars pay more attention to the environmental impact of mineral resources development. Chang et al. [29] analyzed China's environmental laws on the Marine utilization of mineral resources by combining qualitative and quantitative methods, and believed that China's environmental laws on mineral resources could learn some lessons from the practices of Germany, the Czech Republic and other countries. Omotehinse and Ako [30] have analyzed the environmental impact of the utilization of mineral resources in Nigeria, and the findings have enabled Nigeria to implement and enforce certain minimum environmental standards for solid mineral exploration and exploitation. Kaniki and Tumba [31] conducted chemical analysis on samples from the Congo copper belt and found that waste from mine development caused serious harm to the environment. Kaikkonen et al. [32] combined empirical evidence from experimental seabed mining and parallel industries to infer the impact of seabed mineral mining on Marine ecosystem.

The development and utilization of mineral resources is an important guarantee for the stable operation of national economy. How to evaluate the impact of environmental protection policies and regulations on the utilization of mineral resources [10], and based on this, to study the construction and optimization of regulatory policy system, is the key issue to realize the win-win situation of mineral resources safe supply guarantee and ecological environment protection. The exploitation and utilization of mineral resources have been greatly restricted as the Chinese government has imposed stronger control on the ecological environment for the utilization of mineral resources. Wang and Guo [33] discussed the impact of energy and the utilization of mineral resources and environmental regulation on economic growth in western China, and found that environmental regulation had a positive effect on economic development in western China, but it lagged behind by one year. Wang et al. [34] established a calculable general equilibrium (CGE) model to study the market impact of environmental regulation on China's rare earth production, and the results showed that strengthening environmental regulation on rare earth production would have a negative impact on the macro economy. Gao et al. [35] examined the direct and indirect effects of environmental regulation on the green development of mining industry and its transmission mechanism, and found that there was a U-shaped nonlinear relationship between the intensity of environmental regulation and the green level of mining industry. Chen and Cheng [36] investigated the environmental impact of the development and utilization of mineral resources in China, and found that the environmental impact of the exploitation and utilization of mineral resources in China had a lag effect, and the environmental pollution in the early stage had a significant impact on the environment in the current period. The existing literature pays more attention to the impact of exploitation and utilization of mineral resources on the environment, while there is little discussion on the adverse effect of environmental regulations on the optimal allocation of mineral resources.

Based on the literature review, it is found that most of the existing literature studies are based on the country as a unit, and few studies are divided into domestic or specific economic regions for comparison. The whole industry chain of mineral resources is accompanied by the destruction of the ecological environment and the strengthening of 
environmental control. With the increase of the restriction intensity of the utilization of mineral resources in China, local governments prefer to reduce the utilization of mineral resources indirectly by improving the utilization rate of mineral resources, so as to reach the goal of ecological environmental protection. The industrial structure, technological progress, government management and other factors play an important role in the ecological environment of mineral resources. Some literature studies tend to study the role of industrial structure, technological progress and government management by qualitative methods. Although CGE and other models can simulate the impact of mineral resources on the ecological environment, the results may be significantly different from the actual situation because of the non-temporal effect of the input-output table. China is the largest developing country in the world. The exploitation and utilization of mineral resources are large in scale, high in intensity, serious in environmental pollution and varied in time and space. On this basis, 30 provinces in China and the eastern, central and western regions of China are taken as research objects. The study on the middle and lower reaches of the whole industrial chain of mineral resources is conducive to the government to rationally adjust the utilization of mineral resource, improve the efficient utilization of mineral resources, reduce the development amount of mineral resources in the upper reaches, and ultimately reduce the damage to the ecological environment. From the perspective of interaction effect and space, this paper studies the impact of the exploitation and utilization of mineral resources on ecological environment and the impact of environmental regulation on the exploitation and utilization of mineral resources based on the collaborative structure of industrial structure, technological progress and government management status, and discusses the impact mechanism and path in depth. The results of this paper promote the efficient utilization of mineral resources in the whole industrial chain so as to make a marginal contribution to the progress of mineral resources management in China.

\section{Models and Variables}

\subsection{The Empirical Models}

Spatial factors play an important role in the utilization of mineral resources in China. With the convenience of transportation and communication between regions, the policies and manufacturing industries in this region will gradually have an impact on the surrounding areas. If the level of environmental regulation is high in this region, the corresponding enterprises will transfer to the regions with a low level of environmental regulation in the surrounding regions to reduce costs. The production of enterprises will also consider the problem of substitution processing. If the level of environmental regulation is improved, enterprises will often process raw materials with high pollution and emissions from the factories in the surrounding areas to minimize the cost. This enterprise is only responsible for environmental pollution and gas emission from secondary products to finished products, which often bring environmental pollution to the surrounding areas. The establishment of the environmental sanctuary hypothesis requires the joint governance among provinces concerned, and the formulation of environmental regulation policies and measures and the allocation of environmental resources should fully consider the linkage effect of policies [37]. Based on this, according to the relevant literature of spatial econometrics [38-40], considering the applicability of the model and the need of the research in this paper, the spatial Durbin model (SDM) is finally selected as the basic model to measure the environmental impact of the utilization of mineral resources in China, and to examine the mutual influence of geographical location characteristics on the utilization of mineral resources and the environment. This is shown in Equation (1).

$$
Y=\lambda W Y+\beta_{1} X+\beta_{2} W X+\mu_{\mathrm{i}}+v_{t}+\varepsilon_{i t}
$$

where $Y$ denotes the dependent variable. $X$ denotes the independent variables. $W$ represents the spatial weight matrix. WY represents the spatial lag term of the dependent variable. $W X$ represents the spatial lag term of the independent variables. $\mu_{i}$ and $v_{t}$ are the fixed effect. $\varepsilon_{i t}$ represents the random disturbance term. 
To examine the relationship between relevant factors and the environmental impact of the utilization of mineral resources in China, this paper constructs a general model with interactive terms, as shown in Equation (2).

$$
y_{i t}=\beta_{0}+\beta_{1} x_{1 t}+\sum_{j=2}^{n} \beta_{j} x_{j t}+\sum_{j=2}^{n} \beta_{j} x_{1 t} x_{j t}+v_{i}+\mu_{t}+\varepsilon_{i t}
$$

where $y_{i t}$ denotes the dependent variable. $x_{i t}$ denotes the main control variable. $\sum_{j=2}^{n} \beta_{j} x_{j t}$ represents other control variables. $x_{1 t} x_{j t}$ is the interaction term between $x_{1 t}$ and $x_{j t}$, representing the marginal impact of the main independent variable $x_{1 t}$ on the dependent variable $y_{i t}$.

To analyze the influence of the interactive synergistic effect of the independent variable on the dependent variable, take the first partial derivative of $x_{1 t}$ on both sides of Equation (2), as shown in Equation (3).

$$
\frac{\partial y_{i t}}{\partial x_{1 t}}=\beta_{1}+\sum_{j=2}^{n} \beta_{j} x_{j t}
$$

Among them, the effect of $x_{1 t}$ on $y_{i t}$ depends on $\sum_{j=2}^{n} \beta_{j} x_{j t}$. If $\beta_{j}>0$, the influence of $x_{1 t}$ on $y_{i t}$ increases with the increase of $x_{j t}$, that is, the "Synergy Effect". Conversely, if $\beta_{j}<0$, the intensity of the influence of $x_{1 t}$ on $y_{i t}$ decreases as $x_{j t}$ increases.

By taking the first partial derivative of $x_{j t}$ on both sides of Equation (3), we can obtain the mediating effect of $x_{j t}$ as the mediating variable on $x_{1 t}$ and $y_{i t}$. The result is shown in Equation (4).

$$
\frac{\partial^{2} y_{i t}}{\partial x_{1 t} \partial x_{j t}}=\frac{\partial\left(\frac{\partial y_{i t}}{\partial x_{1 t}}\right)}{\partial x_{j t}}=\beta_{j}
$$

Therefore, the regression coefficient $\beta_{j}$ before the Interaction term is also called "Interaction Effect", or "Moderating Effect", that is, the degree to which $x_{1 t}$ 's Effect on $y_{i t}$ is affected by $x_{j t}$.

\subsection{Variables}

Environmental Regulation: The calculation method of the environmental regulation refers to the research of Zhu et al. [41], in which the relative emission level of urban $i$ type $l$ pollution is defined, as shown in Equation (5).

$$
p x_{l i}=\frac{p_{l i}}{\frac{1}{n} \sum_{j=1}^{n} p_{l j}}, l=1,2, \ldots, 5
$$

where $p_{l i}$ is the emission of the $l$ kind of pollution unit GDP of the city $i$. Considering the realistic correlation between the utilization of mineral resources and the discharge of industrial pollutants, this paper first selects five kinds of pollutants, which include industrial wastewater, industrial waste gas, industrial $\mathrm{SO}_{2}$, industrial smoke (powder) dust and industrial solid waste. The larger the value of $p x_{l i}$ and the greater than 1 , the emission of Class $l$ pollutants in city $i$ is higher at the national level. Since $p x_{l i}$ itself is a dimensionless variable, the environmental adjustment index is calculated based on the entropy weight method.

Environmental Pollution: Considering the practical relevance between the utilization of mineral resources and the discharge of industrial pollutants, this paper firstly selects five pollutant discharges, such as industrial waste water, industrial waste gas, industrial $\mathrm{SO}_{2}$, industrial smoke (powder) dust and industrial solid waste, to calculate the environmental pollution index by entropy weight method. 
Utilization of Mineral Resources: It is difficult to obtain the data of the utilization of mineral resources from the perspective of terminal consumption because the statistics department does not disclose the consumption of metal mineral resources in each region. However, the period examined in this paper is an important stage of China's industrialization and urbanization, and is also a key period for rapid economic growth, the development of the mineral products market and strong demand. During this period, the strong expansion of infrastructure construction and factor market, promoting the improvement of the minerals production level, wide usage and the market demand in the field of iron metal products, became the supporting economic development of the basic means of production, and the production or consumption greatly reflect the overall situation of metal the utilization of mineral resources. Therefore, referring to the setting of the utilization of mineral resources index by Chen and Cheng [36], this paper takes pig iron output as the indicator to measure the utilization of mineral resources. In the robustness test, coal consumption and cement production are used as indicators to measure the development and utilization of energy and non-metallic mineral resources.

Industrial Structure: The formation and change of industrial structure are usually affected by factors such as regional division of labor, production factor flow, market development degree and inter-regional trade. This paper selects the proportion of secondary industry and total freight volume as indicators to measure the industrial structure and utilizes entropy rights, and uses the entropy weight method to calculate industrial structure indicators.

Technical Progress: Because FDI and R\&D have an impact on the level of technological progress in economic growth from the aspects of technology spillover and internal innovation, some mature production technologies are put into the production process through the market, which promotes the improvement of technological innovation level. Therefore, FDI, R\&D and technology market turnover were selected as the main parameters to measure technological progress, and finally, the entropy weight method was used to calculate the technical progress indicators.

Government Management Status: The role of government regulation is mainly reflected in the government's actions on environmental pollution control and the effectiveness of resource utilization and environmental improvement. Therefore, this paper selects the investment completion amount of industrial pollution control as an indicator to measure the government's efforts on environmental governance, and selects the amount of industrial pollution control investment completion, the number of environmental emergencies, industrial wastewater treatment investment and environmental petition as a measure of government environmental management. As indicators of effectiveness, finally, the entropy weight method was used to calculate the government's environmental regulation status indicators.

Spatial Weight Matrix: In this paper, the $0-1$ adjacency matrix of Queen type is selected to describe the adjacent cities. When there is a boundary between city $i$ and city $j$ boundary, $\omega_{i j}$ is equal to 1 ; otherwise $\omega_{i j}$ is equal to 0 .

The data is mainly from the China Statistical Yearbook on Environment, China Statistical Yearbook and EPS data platform. Among them, the China Statistical Yearbook on Environment is jointly edited by the National Bureau of Statistics and the Ministry of Environmental Protection and published by China Statistical Press. The China Statistical Yearbook on Environment is one of the most authoritative environmental data sources in China. Its content is divided into 12 parts, including natural conditions, water environment, atmospheric environment and so on. Meanwhile, the China Statistical Yearbook is an informative annual publication compiled and published by the National Bureau of Statistics, which comprehensively reflects the economic and social development of China. The statistical yearbook of a certain year contains a large number of statistics of the whole country and of the provinces, autonomous regions and municipalities directly under the central government in various aspects of the economy and society of the previous year, as well as major statistics of the whole country in important years and in the past 20 years. 
Published annually by the National Bureau of Statistics, it is the most comprehensive and authoritative comprehensive statistical yearbook in China. The EPS (Easy Professional Superior) data platform is a data information service platform integrating rich numerical data resources and powerful econometric system. The EPS is a large-scale integrated data platform that integrates all kinds of data resources. It comprises international data, macroeconomic and financial market, industry operation, regional economic, trade, resources and environment data, counties and cities, humanities and social science, census data, multiple database cluster, contains 86 databases, where the article has more than 250,000 statistical indicators of time series, data amounted to 4 billion, and is increasing at a speed of about 200 million each year. The values missing from the individual indicators were repaired using the mean method. Before data analysis, the data for each variable was logarithmically processed to eliminate the heteroscedasticity present in the data. The stability of the variables was examined in this paper, and all variables pass the stationarity test.

\section{Results}

\subsection{Spatial Correlation Test}

Spatial correlation is the premise of spatial econometric model application. If there is a correlation between variables in spatial units, the spatial econometric model is more suitable for application. However, if there is not any correlation between variables in spatial units, it indicates that variables have no spatial correlation characteristics and the spatial econometric model is not applicable to this problem. The most commonly used test index of spatial correlation is the Moran's I index. If Moran's I is larger than 0 and significant, it indicates that the variable has a positive spatial correlation, presents spatial agglomeration characteristics in space, and indicates that the spatial econometric model is suitable for the analysis of this variable. This paper mainly carries out a spatial correlation test for environmental pollution and the utilization of mineral resources. The results of the spatial correlation test index Moran's I are shown in Figure 1.

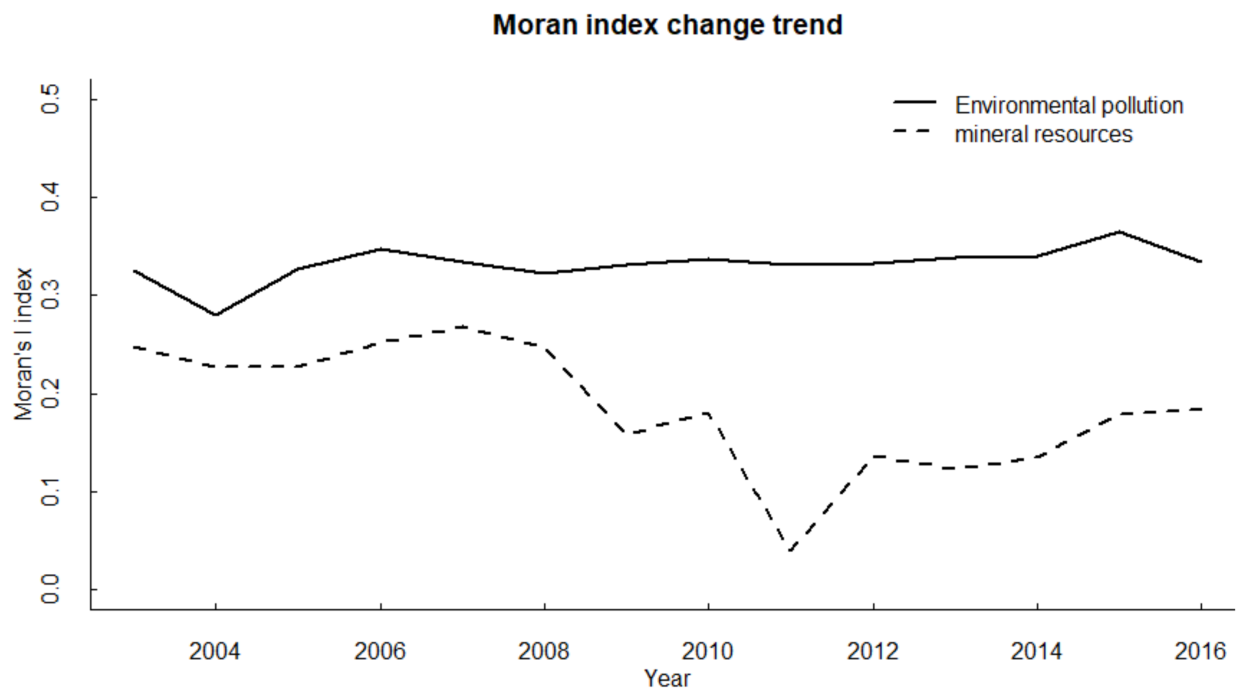

Figure 1. Spatial correlation between environmental pollution and the utilization of mineral resources.

There is a significant positive correlation between environmental pollution and the utilization of mineral resources. As shown in Figure 1, the Moran's I of environmental pollution and the utilization of mineral resources are both greater than 0 , and it is found through $\mathrm{Z}$ test that the Moran value of each point is significant. The results show that there is a significant positive correlation between environmental pollution and the utilization of mineral resources, and spatial agglomeration. Therefore, the space econometric model selected in this paper is more suitable. 


\subsection{The Environmental Impact of the Utilization of Mineral Resources in China}

Mineral resources, while effectively supporting China's rapid economic and social development, have also brought huge damage to environmental pollution. To control environmental pollution, in recent years, Chinese provincial and municipal governments have continuously intensified environmental governance efforts, and formulated many environmental protection and governance policies, such as environmental regulation [42] and carbon emission trading [43]. In the existing literature, most scholars believe that environmental regulation is one of the most effective policies to control environmental pollution. This part empirically analyzes the impact of China's utilization of mineral resources on environmental pollution and environmental regulation on the utilization of mineral resources based on the spatial econometric model. The results are shown in Table 1.

Table 1. The environmental impact of the utilization of mineral resources.

\begin{tabular}{|c|c|c|c|c|c|c|c|c|}
\hline \multirow{2}{*}{ Variates } & \multicolumn{4}{|c|}{$\begin{array}{c}\text { The Effect of Utilization of Mineral Resources on } \\
\text { Environmental Pollution }\end{array}$} & \multicolumn{4}{|c|}{$\begin{array}{c}\text { The Influence of Environmental Regulation on } \\
\text { Utilization of Mineral Resources }\end{array}$} \\
\hline & Coef. & $\begin{array}{l}\text { Direct } \\
\text { Effect }\end{array}$ & $\begin{array}{l}\text { Indirect } \\
\text { Effect }\end{array}$ & $\begin{array}{c}\text { Total } \\
\text { Effect }\end{array}$ & Coef. & $\begin{array}{l}\text { Direct } \\
\text { Effect }\end{array}$ & $\begin{array}{l}\text { Indirect } \\
\text { Effect }\end{array}$ & $\begin{array}{l}\text { Total } \\
\text { Effect }\end{array}$ \\
\hline MR & $\begin{array}{l}0.07 * * \\
(2.28)\end{array}$ & $\begin{array}{l}0.06^{* *} \\
(2.09)\end{array}$ & $\begin{array}{l}-0.15^{* * *} \\
(-2.55)\end{array}$ & $\begin{array}{l}-0.09 \\
(-1.47)\end{array}$ & & & & \\
\hline ER & & & & & $\begin{array}{l}0.50 * * * \\
(5.03)\end{array}$ & $\begin{array}{l}0.60 * * * \\
(5.63)\end{array}$ & $\begin{array}{l}1.58^{* * *} \\
(4.48)\end{array}$ & $\begin{array}{l}2.18^{* * *} \\
(5.28)\end{array}$ \\
\hline Ind & $\begin{array}{l}0.24^{* * *} \\
(4.93)\end{array}$ & $\begin{array}{l}0.24 * * * \\
(5.22)\end{array}$ & $\begin{array}{c}0.25^{* * *} \\
(2.65)\end{array}$ & $\begin{array}{c}0.49^{* * *} \\
(5.30)\end{array}$ & $\begin{array}{c}0.20 * * * \\
(2.66)\end{array}$ & $\begin{array}{c}0.25^{* * *} \\
(3.56)\end{array}$ & $\begin{array}{c}0.78^{* * *} \\
(5.78)\end{array}$ & $\begin{array}{c}1.03^{* * *} \\
(7.85)\end{array}$ \\
\hline Tec & $\begin{array}{c}0.02 \\
(0.75)\end{array}$ & $\begin{array}{c}0.02 \\
(0.93)\end{array}$ & $\begin{array}{c}0.08 \\
(1.52)\end{array}$ & $\begin{array}{l}0.10 * \\
(1.75)\end{array}$ & $\begin{array}{l}0.06 \text { * } \\
(1.84)\end{array}$ & $\begin{array}{c}0.04 \\
(1.09)\end{array}$ & $\begin{array}{c}-0.36^{* * *} \\
(-3.98)\end{array}$ & $\begin{array}{c}-0.32^{* * *} \\
(-3.18)\end{array}$ \\
\hline Gov & $\begin{array}{c}0.11^{* * *} \\
(5.51)\end{array}$ & $\begin{array}{c}0.12^{* * *} \\
(6.94)\end{array}$ & $\begin{array}{c}0.33^{* * *} \\
(9.76)\end{array}$ & $\begin{array}{l}0.45^{* * *} \\
(12.88)\end{array}$ & $\begin{array}{l}0.05 * \\
(1.93)\end{array}$ & $\begin{array}{c}0.03 \\
(1.08)\end{array}$ & $\begin{array}{c}-0.41^{* * *} \\
(-8.56)\end{array}$ & $\begin{array}{c}-0.38^{* * *} \\
(-7.78)\end{array}$ \\
\hline $\mathrm{W}^{*} \mathrm{MR}$ & $\begin{array}{c}-0.14 * * * \\
(-2.86)\end{array}$ & & & & & & & \\
\hline$W^{*} E R$ & & & & & $\begin{array}{c}0.91^{* * *} \\
(3.91)\end{array}$ & & & \\
\hline $\mathrm{W}^{*}$ Ind & $\begin{array}{l}0.14 \text { * } \\
(1.69)\end{array}$ & & & & $\begin{array}{c}0.47^{* * *} \\
(4.15)\end{array}$ & & & \\
\hline $\mathrm{W}^{*} \mathrm{Tec}$ & $\begin{array}{c}0.06 \\
(1.38)\end{array}$ & & & & $\begin{array}{c}-0.27^{* * *} \\
(-4.36)\end{array}$ & & & \\
\hline $\mathrm{W}^{*}$ Gov & $\begin{array}{c}0.24^{* * *} \\
(7.11)\end{array}$ & & & & $\begin{array}{c}-0.30 * * * \\
(-7.78)\end{array}$ & & & \\
\hline$W^{*}$ dep.var. & $\begin{array}{c}0.23^{* * *} \\
(3.87)\end{array}$ & & & & $\begin{array}{c}0.35^{* * *} \\
(6.50)\end{array}$ & & & \\
\hline $\begin{array}{c}\text { Regional fixation } \\
\text { effect }\end{array}$ & Yes & & & & Yes & & & \\
\hline Time fixation effect & Yes & & & & Yes & & & \\
\hline $\mathrm{R}^{2}$ & 0.95 & & & & 0.94 & & & \\
\hline log-likelihood & -1203.37 & & & & -2413.50 & & & \\
\hline
\end{tabular}

Notes: ${ }^{*}{ }^{* *}$ and ${ }^{* * *}$ indicate significant at the significance level of $10 \%, 5 \%$ and $1 \%$, respectively.

The utilization of mineral resources and environmental pollution show the characteristics of spatial agglomeration. According to the Table 1, the $\mathrm{W}^{*}$ dep.var. represents the spatial influence of the dependent variable. The spatial lag coefficient of environmental pollution is 0.23 , and the spatial lag coefficient of the utilization of mineral resources is 0.35 , both of which are significant at $1 \%$. It indicates that the deterioration of environmental pollution and the utilization of mineral resources have a significant positive impact on the 
adjacent areas. For every unit of environmental pollution worsening in the central area, the environmental pollution in the adjacent area will worsen by 0.23 units. Each additional unit of mineral resources in the central area leads to an additional 0.35 units of mineral resources in the adjacent area. Environmental pollution and the utilization of mineral resources have a significant impact on environmental pollution and the utilization of mineral resources in the adjacent areas. As the largest developing country, China has witnessed remarkable industrial development and rapid economic development since the reform and opening up. The GDP growth rate is among the highest in the world. The increasing demand for mineral resources in infrastructure construction and factor market promotes the spatial flow of mineral resource products. Because the country's mineral resources distribution is relatively concentrated, each region has its own superiority mineral resources. Strong inter-provincial exchanges and cooperation enhanced the mobility of mineral resources. Combined with the diversity of accessories and industrial agglomeration, the utilization degree of mineral resources is significantly related in space.

The utilization of mineral resources aggravates environmental pollution in this area and significantly reduces the environmental pollution in the neighboring areas. The utilization of mineral resources reflects the utilization amount of the primary processing of mineral resources in the region, and the impact intensity of the utilization of mineral resources on environmental pollution is 0.07 , while the impact intensity of environmental pollution in the adjacent region is -0.14 , both of which are significant. The utilization of mineral resources has a significant impact on the environment, with each additional unit of mineral resources causing 0.07 units of environmental pollution. Combined with direct effect and indirect effect, it is found that the direct effect of the utilization of mineral resources on environmental pollution is 0.06 , but the indirect effect is -0.15 , both of which are significant. The utilization of mineral resources worsened environment, but indirectly inhibits environmental pollution. Combined the utilization of mineral resources in the neighborhood, found that the influence of the utilization of mineral resources significantly inhibited the pollution of the environment in the neighborhood. Therefore, this paper holds that the total utility of the utilization of mineral resources significantly inhibited the pollution of the environment. The primary processing products of mineral resources in a region are not all consumed in the whole industrial chain of the region, and the subsequent processing and manufacturing processes are still needed. The primary processing products of mineral resources not only meet the needs of the region, but also are transported to other regions, providing raw materials for infrastructure construction and factor markets in other regions, reducing the primary processing output of such mineral resources and ultimately reducing the environmental pollution in neighboring regions.

Environmental regulations effectively inhibit the utilization of mineral resources in this region and adjacent areas. The impact intensity of environmental regulation on the utilization of mineral resources in this region and adjacent regions is 0.50 and 0.91 , respectively, and both are significant at the significance level of $1 \%$. Since the environmental regulation index in this paper is negative, that is, the smaller the value of the variable, the stricter the implementation of environmental regulation in this region. According to the results, each additional unit of environmental regulation significantly inhibited the utilization of mineral resources in this region, with an inhibitory intensity of 0.50 and 0.91 . Among the policies and regulations of environmental governance, environmental regulation is generally recognized as a better means to deal with environmental problems and has been recognized by a large number of scholars and government departments. The utilization of mineral resources intensifies environmental pollution, and environmental regulation is the most effective means to solve environmental pollution. Therefore, environmental regulation indirectly inhibits the utilization of mineral resources through environmental pollution control.

The improvement of industrial structure not only aggravates environmental pollution, but also increases the utilization of mineral resources. The total effect of industrial structure on environmental pollution is 0.49 , and the total effect of industrial structure 
on the utilization of mineral resources is 1.03. Industrial structure has a significant positive effect on environmental pollution and increases the utilization of mineral resources. The improvement of industrial structure speeds up the production speed and efficiency, but with the improvement of production capacity, it increases the utilization of mineral resources. Because of the impact of production on the environment, the improvement of the industrial structure has a significant impact on the environment.

The improvement of technological progress has increased the utilization of mineral resources in this region and inhibited the utilization of mineral resources in neighboring regions. The impact of technological progress on environmental pollution is not significant, but its overall effect on environmental pollution is positive; the impact intensity is 0.10 , and the significance is significant at $10 \%$. It indicates that with the enhancement of technological progress, environmental quality has been significantly reduced. However, technological progress has significantly enhanced the utilization of mineral resources, but inhibited the utilization of mineral resources in the adjacent areas. Therefore, the utilization of mineral resources increases with the enhancement of technological progress. However, the technological progress has a significant local protection nature and has a weak influence on the neighboring areas. With the increase in the utilization of mineral resources in the regions with higher technology, the flow of products between regions and the influence of manufacturing costs and other factors lead to more purchase of products from neighboring regions. Therefore, to some extent, the utilization of mineral resources in adjacent areas is inhibited. It can also be seen from the results of direct effect, indirect effect and the total effect that the direct effect of technological progress on the utilization of mineral resources is positive, but not significant. The indirect effect and total effect on the utilization of mineral resources are significantly negative.

Government management has significantly curbed environmental pollution and increased the utilization of mineral resources. The impact of government management on environmental pollution in and around the region is significantly positive. Since government management is a negative indicator, the higher the value of government management is, the smaller the degree of government management is. Therefore, this result indicates that government management significantly inhibits environmental pollution, and the impact intensity of government management on environmental pollution in adjacent areas is 0.24. Although government management has significantly curbed environmental pollution, its impact on neighboring areas is significantly greater than that in local areas. Through the analysis of the indirect effect of government management on environmental pollution, it is found that the direct effect, indirect effect and total effect of government management on the utilization of mineral resources are all significantly positive, indicating that government management significantly inhibits environmental pollution. Further, government management has inhibited the utilization of mineral resources in the region, but promoted the utilization of mineral resources in neighboring areas. Government regulation has facilitated the transfer of mineral resources to neighboring areas. Through analyzing the indirect effect of government management, it is found that although the direct effect of government management on the utilization of mineral resources is positive, while the indirect effect and the total effect are negative. Government management promotes the utilization of mineral resources.

China is in the stage of industrialization and upgrading, and industrial technology and equipment are constantly upgraded. The development of industrial structure, especially the modern industrial structure system driven by industrialization, has a positive effect on environmental pollution and is relatively obvious. Government management, as an important force to restrain environmental pollution, has a significant inhibitory effect on environmental pollution. At the same time, China's government management in the utilization of mineral resources has also played a positive role in the control of environmental pollution. However, it is found from the impact coefficient that although technological progress has a significant inhibitory effect on environmental pollution, its impact intensity is small, and the environmental pollution in this region and surrounding areas is not 
significant. While further strengthening the government's environmental supervision, optimizing the industrial structure and strengthening the application and diffusion of modern high and new technology in the utilization of mineral resources are the important directions of resource and environmental protection in China.

Among the main influencing factors of the utilization of mineral resources, environmental regulation and technological progress significantly inhibit the utilization of mineral resources. Environmental regulation, as an external force, inhibits the utilization of mineral resources, which is not conducive to the development of the industry to some extent. According to the influence coefficient, external forces are significantly stronger than internal forces. Although China has the ability to curb the degree of environmental pollution, the level of innovation spillover is relatively low due to the boundary protection phenomenon in the level of technological innovation, and the synchronous pollution control and emission reduction effect based on technological innovation cannot be truly realized. The industrial structure promoted economic growth, which significantly increased the utilization degree of mineral resources. Although government management promotes the transfer of the utilization of mineral resources to neighboring areas, the overall effect on the utilization of mineral resources is a significant promotion effect, that is, government management increases the utilization of mineral resources.

\subsection{Results of Different Spatial Weight Matrices}

The research conclusion is based on the spatial relationship of the queen's first order, and the transfer of resources is not mainly based on the area, but also more of the supply and demand, as the cost of transportation decreases and the regional cooperation is strengthened. Therefore, to analyze the influence of different distances and economic development levels on the above conclusions, this part refers to the weight matrix set by Jin and Sheng (Jin and Shen 2018) and selects the economic distance weight matrix and geographical distance weight matrix to analyze the environmental impact of the utilization of mineral resources in China under different spatial weight matrices. Economic distance weight matrix (W2): $\omega_{i j}=1 /\left|p g d p_{i}-p g d p_{j}+1\right|$, where pgdp is per capita GDP. Geographic distance weight matrix (W3). The $\omega_{i j}$ represents the reciprocal of the distance between city $i$ and city $j$. Unlike the $0-1$ matrix, this matrix assumes that interactions between any city are possible, except those closer cities have more pronounced interactions. Different from the idea of constructing a spatial weight matrix from the perspective of geographical distance, the economic distance weight matrix measures the proximity between cities by economic distance (the difference in GDP per capita). To make the spatial lag term have the meaning of weighted average, the above two matrices are normalized and the diagonal element is set as 0 . The regression results are shown in Table 2.

The spatial relationship of the economic level is the main way that the utilization of mineral resources affects environmental pollution. According to the results in the Table 2, among the three spatial weight matrices, when the spatial weight matrix is the geographical distance weight matrix (W3), the coefficient of environmental pollution hysteresis term is the largest. It indicates that the main influence path of environmental pollution transfer is the spatial relationship of geographical distance. The closer the geographical distance is, the stronger the environmental pollution intensity is in the adjacent area. By comparing the influence intensity of the utilization of mineral resources on environmental pollution in the model with three spatial weight matrices as spatial relation, it is found that the coefficient value of spatial relation with spatial weight matrix of economic distance is the largest. The main flow path of primary processing products of mineral resources is the spatial relationship of economic proximity.

Environmental regulation mainly inhibits the utilization of mineral resources in the regions close to each other, and has the weakest inhibitory intensity on the spatial relation of economic level. By comparing the three coefficients of environmental regulation's influence on the utilization of mineral resources, it is found that the influence intensity is the strongest in the model with close distance as the spatial relation, and the influence intensity is 1.21. 
It indicates that the spillover effect of environmental regulation on geographically distant regions is significantly greater than that on economically and geographically adjacent regions. According to the interregional environmental regulation enforcement interaction, the main path of interregional environmental regulation enforcement interaction is adjacent regions. However, the influence of environmental regulation on the utilization of mineral resources is the least in the model with economic level as the spatial relation, indicating that environmental regulation has a weak influence on the utilization of mineral resources in similar economic level areas. Combined with the approach of the impact of the utilization of mineral resources on environmental pollution, it is found that the utilization of mineral resources in adjacent economic areas is weakly affected by environmental regulations in adjacent areas, which ultimately affects the utilization of mineral resources and the degree of environmental pollution, which is consistent with the conclusion above.

Table 2. Environmental impacts of the utilization of mineral resources based on different spatial weight matrices.

\begin{tabular}{|c|c|c|c|c|}
\hline \multirow{2}{*}{ Variates } & \multicolumn{2}{|c|}{$\begin{array}{l}\text { The Effect of Utilization of Mineral Resources } \\
\text { on Environmental Pollution }\end{array}$} & \multicolumn{2}{|c|}{$\begin{array}{c}\text { The Influence of Environmental Regulation on } \\
\text { Utilization of Mineral Resources }\end{array}$} \\
\hline & $\begin{array}{l}\text { W2 } \\
\text { (1) }\end{array}$ & $\begin{array}{l}\text { W3 } \\
\text { (2) }\end{array}$ & $\begin{array}{l}\text { W2 } \\
\text { (3) }\end{array}$ & $\begin{array}{l}\text { W3 } \\
\text { (4) }\end{array}$ \\
\hline MR & $\begin{array}{l}0.11 * * * \\
(3.61)\end{array}$ & $\begin{array}{l}0.09 * * * \\
(2.86)\end{array}$ & & \\
\hline ER & & & $\begin{array}{c}0.39 * * * \\
(3.86)\end{array}$ & $\begin{array}{c}0.37^{* * *} \\
(3.67)\end{array}$ \\
\hline $\mathrm{W}^{*} \mathrm{MR}$ & $\begin{array}{l}-0.29 * * * \\
(-5.02)\end{array}$ & $\begin{array}{l}-0.18^{* *} \\
(-2.23)\end{array}$ & & \\
\hline $\mathrm{W}^{*} \mathrm{ER}$ & & & $\begin{array}{l}0.64 * \\
(1.92)\end{array}$ & $\begin{array}{l}1.21 * * \\
(2.02)\end{array}$ \\
\hline$W^{*}$ dep.var. & $\begin{array}{l}0.26^{* * *} \\
(3.64)\end{array}$ & $\begin{array}{l}0.46^{* * *} \\
(5.10)\end{array}$ & $\begin{array}{c}0.38 * * * \\
(5.88)\end{array}$ & $\begin{array}{l}0.42^{* * *} \\
(4.44)\end{array}$ \\
\hline Regional fixation effect & Yes & Yes & Yes & Yes \\
\hline Time fixation effect & Yes & Yes & Yes & Yes \\
\hline$R^{2}$ & 0.94 & 0.94 & 0.94 & 0.94 \\
\hline log-likelihood & -2980.99 & -1170.07 & -1264.73 & -4395.94 \\
\hline
\end{tabular}

Notes: ${ }^{* * *}$ and ${ }^{* * *}$ indicate significant at the significance level of $10 \%, 5 \%$ and $1 \%$, respectively.

\subsection{Heterogeneous Results in Different Regions}

Because China is a large country, and in the east development is uncoordinated, economy, culture, science and technology have significant differences. With the background of this kind of difference existing in the utilization of mineral resources of environmental pollution, and as the influence of environmental regulation on the influence of the utilization of mineral resources is significantly different, so the analysis of the above results cannot represent the status of the various regions. To analyze the situation in different regions, this part studies different regions of China by using the method above. According to Chen's [29] criteria for the division of China's provinces, the 30 provinces in China, except Hong Kong, Macao, Taiwan and Tibet, are divided into eastern, central, western and northeastern regions. The detailed partition results are shown in Figure 2 and Table 3. 


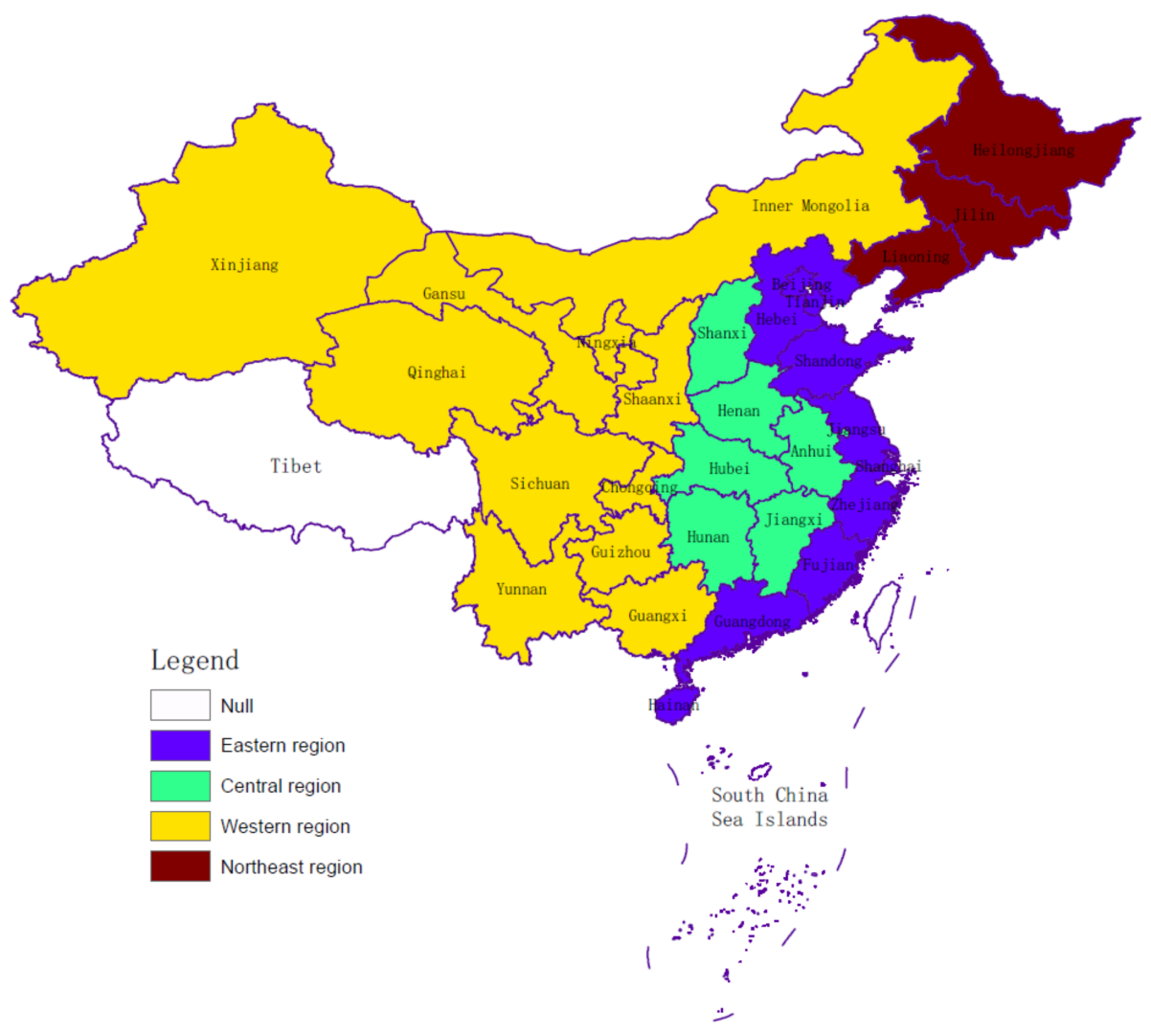

Figure 2. China regional division standard.

Table 3. China regional division standard.

\begin{tabular}{ccccc}
\hline & Eastern (10) & Central (6) & Western (11) & Northeast (3) \\
\hline & $\begin{array}{c}\text { Beijing, Tianjin, Hebei, } \\
\text { Shandong, Jiangsu, } \\
\text { Shanghai, Zhejiang, } \\
\text { Fujian, Guangdong and } \\
\text { Hainan }\end{array}$ & $\begin{array}{c}\text { Henan, Hubei, Hunan, } \\
\text { Anhui, Jiangxi and } \\
\text { Shanxi }\end{array}$ & $\begin{array}{c}\text { Chongqing, Sichuan, } \\
\text { Yunnan, Guizhou, }\end{array}$ & $\begin{array}{c}\text { Guangxi, Shaanxi, } \\
\text { Gansu, Ningxia, } \\
\text { Xinjiang, Qinghai and } \\
\text { Inner Mongolia }\end{array}$ \\
\hline
\end{tabular}

According to the regional classification standards of 30 provinces in Figure 2 and Table 3, the influence of the utilization of mineral resources in the different regions of China on environmental pollution and the influence of environmental regulation on the utilization of mineral resources were analyzed by using the model structure above, respectively, as shown in Table 4.

Environmental regulations promote the utilization of mineral resources from central China to neighboring regions. The improvement of environmental regulation promotes the transfer of the utilization of mineral resources to the adjacent areas and enhances the utilization degree of mineral resources in the adjacent areas. As the central region is also a major area for the utilization of mineral resources, the industrial structure is relatively complete and the level of economic development is relatively high. Therefore, the central region is capable of industrial structure transformation and upgrading and efficient pollution control and emission reduction. The improvement of environmental regulations leads to the transfer of the utilization of mineral resources to neighboring regions, which strengthens the environmental governance of the region. 
Table 4. The environmental impact of the utilization of mineral resources in different areas.

\begin{tabular}{|c|c|c|c|c|c|c|c|c|}
\hline \multirow{2}{*}{ Variates } & \multicolumn{4}{|c|}{$\begin{array}{c}\text { The Effect of Utilization of Mineral Resources on } \\
\text { Environmental Pollution }\end{array}$} & \multicolumn{4}{|c|}{$\begin{array}{c}\text { The Influence of Environmental Regulation on } \\
\text { Utilization of Mineral Resources }\end{array}$} \\
\hline & $\begin{array}{l}\text { Eastern } \\
\text { (1) }\end{array}$ & $\begin{array}{l}\text { Central } \\
\text { (2) }\end{array}$ & $\begin{array}{l}\text { Western } \\
\text { (3) }\end{array}$ & $\begin{array}{l}\text { Northeast } \\
\text { (4) }\end{array}$ & $\begin{array}{l}\text { Eastern } \\
\text { (5) }\end{array}$ & $\begin{array}{c}\text { Central } \\
\text { (6) }\end{array}$ & $\begin{array}{l}\text { Western } \\
\text { (7) }\end{array}$ & $\begin{array}{c}\text { Northeast } \\
\text { (8) }\end{array}$ \\
\hline MR & $\begin{array}{l}-0.03 \\
(-0.87)\end{array}$ & $\begin{array}{c}0.09 \\
(0.63)\end{array}$ & $\begin{array}{c}-0.01 \\
(-0.16)\end{array}$ & $\begin{array}{c}0.18 \\
(1.52)\end{array}$ & & & & \\
\hline ER & & & & & $\begin{array}{l}0.44 * \\
(1.76)\end{array}$ & $\begin{array}{c}0.38^{* * *} \\
(3.69)\end{array}$ & $\begin{array}{c}0.16 \\
(0.91)\end{array}$ & $\begin{array}{l}0.92^{* * *} \\
(2.99)\end{array}$ \\
\hline $\mathrm{W}^{*} \mathrm{MR}$ & $\begin{array}{l}-0.15^{* * *} \\
(-3.68)\end{array}$ & $\begin{array}{l}-0.40^{* * *} \\
(-2.61)\end{array}$ & $\begin{array}{l}-0.03 \\
(-0.31)\end{array}$ & $\begin{array}{l}-0.37^{* * *} \\
(-2.71)\end{array}$ & & & & \\
\hline$W^{*} E R$ & & & & & $\begin{array}{l}0.91 * \\
(2.28)\end{array}$ & $\begin{array}{l}-0.14 \\
(-0.65)\end{array}$ & $\begin{array}{l}1.05 * * * \\
(2.92)\end{array}$ & $\begin{array}{c}0.54 \\
(1.56)\end{array}$ \\
\hline $\mathrm{W}^{*}$ dep.var. & $\begin{array}{l}0.50^{* * *} \\
(8.55)\end{array}$ & $\begin{array}{l}0.53^{* * *} \\
(7.01)\end{array}$ & $\begin{array}{c}-0.01 \\
(-0.13)\end{array}$ & $\begin{array}{l}-0.24^{* *} \\
(-2.25)\end{array}$ & $\begin{array}{l}0.23 * * * \\
(3.01)\end{array}$ & $\begin{array}{l}0.59 * * * \\
(8.24)\end{array}$ & $\begin{array}{l}0.46^{* * *} \\
(6.20)\end{array}$ & $\begin{array}{l}0.50 * * * \\
(5.63)\end{array}$ \\
\hline $\begin{array}{c}\text { Regional fixation } \\
\text { effect }\end{array}$ & Yes & Yes & Yes & Yes & Yes & Yes & Yes & Yes \\
\hline Time fixation effect & Yes & Yes & Yes & Yes & Yes & Yes & Yes & Yes \\
\hline $\mathrm{R} 2$ & 0.99 & 0.82 & 0.87 & 0.92 & 0.96 & 0.93 & 0.84 & 0.98 \\
\hline log-likelihood & -461.49 & -1005.80 & -2286.84 & $\mathrm{NaN}$ & -2071.50 & -503.04 & -5586.21 & -4792.19 \\
\hline
\end{tabular}

Notes: ${ }^{*}, * *$ and ${ }^{* * *}$ indicate significant at the significance level of $10 \%, 5 \%$ and $1 \%$, respectively.

\subsection{Robustness Test}

To verify the scientific nature and robustness of the above results, this part measures the development and utilization of energy and non-metallic mineral resources by using coal consumption and cement output, and analyzes the impact of the utilization of mineral resources on environmental pollution and environmental regulation on the utilization of mineral resources. The results are shown in Table 5 .

Table 5. Environmental impact robustness test for the utilization of mineral resources.

\begin{tabular}{|c|c|c|c|c|}
\hline \multirow{2}{*}{ Variates } & \multicolumn{2}{|c|}{$\begin{array}{l}\text { The Effect of Utilization of Mineral Resources } \\
\text { on Environmental Pollution }\end{array}$} & \multicolumn{2}{|c|}{$\begin{array}{c}\text { The Influence of Environmental Regulation on } \\
\text { Utilization of Mineral Resources }\end{array}$} \\
\hline & $\begin{array}{l}\text { Cement Output } \\
\text { (1) }\end{array}$ & $\begin{array}{l}\text { Coal Utilization } \\
(2)\end{array}$ & $\begin{array}{l}\text { Cement Output } \\
\text { (3) }\end{array}$ & $\begin{array}{l}\text { Coal Utilization } \\
(4)\end{array}$ \\
\hline MR & $\begin{array}{l}0.26 * * * \\
(5.69)\end{array}$ & $\begin{array}{l}0.23^{* * *} \\
(3.70)\end{array}$ & & \\
\hline ER & & & $\begin{array}{l}0.22 * * * \\
(3.34)\end{array}$ & $\begin{array}{l}0.33 * * * \\
(7.13)\end{array}$ \\
\hline $\mathrm{W}^{*} \mathrm{MR}$ & $\begin{array}{l}-0.43^{* * *} \\
(-6.33)\end{array}$ & $\begin{array}{l}-0.34^{* * *} \\
(-3.31)\end{array}$ & & \\
\hline$W^{*} E R$ & & & $\begin{array}{c}0.44^{* * *} \\
(2.86)\end{array}$ & $\begin{array}{l}0.26^{* *} \\
(2.35)\end{array}$ \\
\hline $\mathrm{W}^{*}$ dep.var. & $\begin{array}{l}0.28 * * * \\
(4.94)\end{array}$ & $\begin{array}{l}0.27^{* * *} \\
(4.66)\end{array}$ & $\begin{array}{l}0.28 * * * \\
(4.80)\end{array}$ & $\begin{array}{l}0.19 * * * \\
(3.02)\end{array}$ \\
\hline Regional fixation effect & Yes & Yes & Yes & Yes \\
\hline Time fixation effect & Yes & Yes & Yes & Yes \\
\hline $\mathrm{R}^{2}$ & 0.95 & 0.95 & 0.94 & 0.97 \\
\hline log-likelihood & -2168.67 & -1211.08 & -1874.19 & -1358.04 \\
\hline
\end{tabular}

Notes: ${ }^{* *}$ and ${ }^{* * *}$ indicate significant at the significance level of $5 \%$ and $1 \%$, respectively. 
As can be seen from the results in Table 5, both the degree of environmental pollution and the degree of the utilization of mineral resources present significant agglomeration phenomena at the spatial level. The enhancement of environmental pollution or the utilization of mineral resources in the central area has a significant positive effect on environmental pollution or the utilization of mineral resources in the neighboring area. Moreover, the utilization of mineral resources aggravates the environmental degradation of the region, but restrains the environmental pollution in the neighboring areas, and the utilization of mineral resources promotes the concentration of environmental pollution. Besides this, environmental regulations not only inhibit the utilization of mineral resources in this region, but also reduce the utilization of mineral resources in neighboring regions. The above conclusions are consistent with the results in Table 1, which once again verifies the environmental impact results of the utilization of mineral resources in China.

\subsection{Cooperative Mechanism Analysis}

To analyze the industrial structure, technology innovation and government management with regard to the environmental impact of mineral resources, is given focus. In this part, a spatial econometric model including interaction terms is constructed to study the environmental impact of mineral resource utilization based on the synergistic mechanism of industrial structure, technological innovation and government management. The results are shown in Table 6.

Table 6. Collaborative mechanism of the environmental impact of the utilization of mineral resources.

\begin{tabular}{|c|c|c|c|c|c|c|c|c|}
\hline \multirow{2}{*}{ Variates } & \multicolumn{4}{|c|}{$\begin{array}{c}\text { The Effect of Utilization of Mineral Resources on } \\
\text { Environmental Pollution }\end{array}$} & \multicolumn{4}{|c|}{$\begin{array}{c}\text { The Influence of Environmental Regulation on } \\
\text { Utilization of Mineral Resources }\end{array}$} \\
\hline & Coef. & $\begin{array}{l}\text { Direct } \\
\text { Effect }\end{array}$ & $\begin{array}{l}\text { Indirect } \\
\text { Effect }\end{array}$ & $\begin{array}{l}\text { Total } \\
\text { Effect }\end{array}$ & Coef. & $\begin{array}{l}\text { Direct } \\
\text { Effect }\end{array}$ & $\begin{array}{l}\text { Indirect } \\
\text { Effect }\end{array}$ & $\begin{array}{l}\text { Total } \\
\text { Effect }\end{array}$ \\
\hline MR(ER) & $\begin{array}{l}0.47^{* * *} \\
(2.75)\end{array}$ & $\begin{array}{c}1.07 * * * \\
(4.30)\end{array}$ & $\begin{array}{l}7.09 * * * \\
(4.47)\end{array}$ & $\begin{array}{c}8.16^{* * *} \\
(4.59)\end{array}$ & $\begin{array}{c}2.39 \\
(1.37)\end{array}$ & $\begin{array}{l}1.26 \\
(0.61)\end{array}$ & $\begin{array}{l}-12.16 \\
(-1.24)\end{array}$ & $\begin{array}{l}-10.90 \\
(-0.98)\end{array}$ \\
\hline Ind*MR (ER) & $\begin{array}{l}-0.01 * \\
(-1.66)\end{array}$ & $\begin{array}{l}-0.04^{* * *} \\
(-4.70)\end{array}$ & $\begin{array}{l}-0.35^{* * *} \\
(-5.70)\end{array}$ & $\begin{array}{l}-0.39 * * * \\
(-5.83)\end{array}$ & $\begin{array}{l}-0.12 * \\
(-1.75)\end{array}$ & $\begin{array}{l}-0.12 \\
(-1.30)\end{array}$ & $\begin{array}{c}0.07 \\
(0.17)\end{array}$ & $\begin{array}{l}-0.04 \\
(-0.09)\end{array}$ \\
\hline Tec*MR(ER) & $\begin{array}{l}-0.01 * \\
(-1.69) \\
\end{array}$ & $\begin{array}{c}0.00 \\
(0.03) \\
\end{array}$ & $\begin{array}{l}0.07 * \\
(1.79)\end{array}$ & $\begin{array}{c}0.07 \\
(1.62) \\
\end{array}$ & $\begin{array}{c}0.05 \\
(1.46) \\
\end{array}$ & $\begin{array}{c}0.04 \\
(0.75) \\
\end{array}$ & $\begin{array}{c}-0.17 \\
(-0.68)\end{array}$ & $\begin{array}{c}-0.13 \\
(-0.47)\end{array}$ \\
\hline Gov*MR(ER) & $\begin{array}{c}0.00 \\
(0.72)\end{array}$ & $\begin{array}{c}0.01 \\
(1.27)\end{array}$ & $\begin{array}{c}0.05 \\
(1.40)\end{array}$ & $\begin{array}{c}0.06 \\
(1.42)\end{array}$ & $\begin{array}{c}-0.02 \\
(-0.52)\end{array}$ & $\begin{array}{c}0.06 \\
(1.17)\end{array}$ & $\begin{array}{c}0.88^{* * *} \\
(3.38)\end{array}$ & $\begin{array}{c}0.94^{* * *} \\
(3.10)\end{array}$ \\
\hline $\mathrm{W}^{*} \mathrm{MR}(\mathrm{ER})$ & $\begin{array}{c}0.87^{* * *} \\
(2.95)\end{array}$ & & & & $\begin{array}{l}-5.70 * \\
(-1.73)\end{array}$ & & & \\
\hline $\mathrm{W}^{*}$ Ind*MR(ER) & $\begin{array}{c}-0.05^{* * *} \\
(-4.16)\end{array}$ & & & & $\begin{array}{c}0.11 \\
(0.76)\end{array}$ & & & \\
\hline $\mathrm{W}^{*} \mathrm{Tec}^{*} \mathrm{MR}(\mathrm{ER})$ & $\begin{array}{c}0.02 * * * \\
(2.63)\end{array}$ & & & & $\begin{array}{c}-0.10 \\
(-1.24)\end{array}$ & & & \\
\hline$W^{*} \operatorname{Gov}^{*} \mathrm{MR}(\mathrm{ER})$ & $\begin{array}{c}0.01 \\
(1.12)\end{array}$ & & & & $\begin{array}{c}0.31^{* * *} \\
(4.06)\end{array}$ & & & \\
\hline $\mathrm{W}^{*} \mathrm{EP}(\mathrm{MR})$ & $\begin{array}{l}0.84^{* * *} \\
(39.29)\end{array}$ & & & & $\begin{array}{l}0.68^{* * *} \\
(19.07)\end{array}$ & & & \\
\hline $\begin{array}{c}\text { Regional fixation } \\
\text { effect }\end{array}$ & Yes & & & & Yes & & & \\
\hline Time fixation effect & Yes & & & & Yes & & & \\
\hline $\mathrm{R}^{2}$ & 0.94 & & & & 0.94 & & & \\
\hline log-likelihood & $-1,088,782.3$ & & & & $-650,430.76$ & & & \\
\hline
\end{tabular}

Notes: * and ${ }^{* * *}$ indicate significant at the significance level of $10 \%$ and $1 \%$, respectively. 
The industrial structure weakens the influence of environmental pollution and environmental regulation on the utilization of mineral resources. According to the results in Table 6, the interaction coefficient between industrial structure and the utilization of mineral resources is significantly negative. Moreover, its direct effect, indirect effect and total benefit are significantly negative. When the utilization of mineral resources remains unchanged, with the improvement of industrial structure, the impact of the utilization of mineral resources on environmental pollution is significantly weakened, and the industrial structure is conducive to the clean production of the utilization of mineral resources. The interaction coefficient between industrial structure and environmental regulation is significantly negative. It can be seen from the above results that environmental regulation inhibits the utilization degree of mineral resources, and with the enhancement of industrial structure, the inhibition degree of environmental regulation on the utilization of mineral resources gradually weakens. Combined with the results of the impact of the utilization of mineral resources on environmental pollution, it can be found that the industrial structure weakens the impact of the utilization of mineral resources on environmental pollution, so the environmental regulation weakens the impact of the utilization of mineral resources. The upgrading of the industrial structure has greatly improved the utilization degree of mineral resources and weakened the environmental pollution caused by it.

Technological progress has suppressed the environmental pollution caused by the utilization of mineral resources in this region, but enhanced the impact of the utilization of mineral resources in adjacent areas on environmental pollution. With the improvement of technological progress, the utilization rate of mineral resources in this region increases gradually and the productivity accelerates, thus restraining the environmental pollution caused by the utilization of mineral resources in this region. Due to the characteristics of technology protection or slow overflow, the adjacent area cannot receive relevant technical support in time, so the existing production technology is still maintained. However, due to the high-tech areas speeding up the production efficiency, to catch up to the production of high-tech areas, meet growing demand, as well as maintain the stability of the existing supply system and existing technology, the adjacent area needs to increase the utilization of mineral resources, eventually leading to the increase of the utilization of mineral resources and damage to the environment pollution.

Government management enhances the impact of environmental regulations on the utilization of mineral resources. The overall effect of the interaction term between government management and the utilization of mineral resources on environmental pollution is positive, indicating that government management significantly enhances the impact of the utilization of mineral resources on environmental pollution. In terms of the influence coefficient of the interaction term between government management and environmental regulation on the utilization of mineral resources, the influence coefficient of this region is negative, the influence coefficient of the adjacent region is significantly positive, and the indirect effect and the total effect are significantly positive. Government management has weakened in this region the effect of environmental regulation on the strength of the utilization of mineral resources. However, in the vicinity, given the intensity of the influence of environmental regulation on the utilization of mineral resources-and, based on the coordination effect of government management, the strength of the utilization of mineral resources-the environmental regulation effect of the total effect is significantly positive. Although government management does not significantly enhance the inhibitory effect of environmental regulations in this region, it can be seen from the overall degree that government management significantly enhances the impact of environmental regulations on the utilization of mineral resources. Government management plays an important role in the restraining effect of environmental regulation on the utilization of mineral resources, which enhances the enforcement of environmental regulation. 


\section{Conclusions and Policy Recommendations}

At present, China has become one of the largest countries in the world in terms of utilization of mineral resources. The exploitation and utilization of mineral resources not only effectively supports the rapid development of China's economy and society, but also brings great damage to the ecological environment. How to avoid the environmental impact caused by the exploitation and utilization of mineral resources is the key problem to break through in the construction of ecological civilization in China. This paper studies the impact of environmental regulation on the utilization of mineral resources from the middle and lower reaches of the whole industrial chain of mineral resources exploitation and utilization, and the influence mechanism of industrial structure, technological progress and government management on the environmental impact of the utilization of mineral resources. The main conclusions are as follows:

First, the utilization of mineral resources aggravates the environmental pollution degree in this region and significantly weakens the environmental pollution degree in adjacent areas. With the increase in the intensity of the utilization of mineral resources, the environmental pollution in this area is significantly aggravated, but the environmental pollution in the adjacent areas is weakened. The utilization of mineral resources leads to the production of more primary processing products, which has a bad impact on the environment. The transportation of primary processing products to neighboring areas provides raw materials for infrastructure construction and factor markets in the neighboring areas, reducing the utilization of mineral resources in the neighboring areas and ultimately reducing the environmental pollution in the neighboring areas.

Second, environmental regulations effectively inhibit the utilization of mineral resources in this region and adjacent regions. Among the policies and regulations of environmental governance, environmental regulation is generally recognized as a better means to deal with environmental problems and has been recognized by a large number of scholars and government departments. The utilization of mineral resources intensifies environmental pollution, and environmental regulation is the most effective means to solve environmental pollution. Therefore, environmental regulation indirectly inhibits the utilization of mineral resources through environmental pollution control.

Thirdly, the spatial relationship of the economic level is the main way that the utilization of mineral resources affects environmental pollution, and environmental regulation mainly inhibits the utilization of mineral resources in areas close to each other. The main flow path of primary processing products of mineral resources is the spatial relationship of economic proximity, and the spillover effect of environmental regulation on geographical distance areas is significantly greater than that on economic proximity and geographical proximity areas.

Fourth, industrial structure, technological progress and government management all have the effect of energy conservation and emission reduction. Among them, the industrial structure weakens the environmental pollution caused by the utilization of mineral resources and the impact of environmental regulations on the utilization of mineral resources. The upgrading of the industrial structure greatly improves the utilization degree of mineral resources and weakens the environmental pollution caused by it. Technological progress has suppressed the environmental pollution caused by the utilization of mineral resources in this region. Government management enhances the impact of environmental regulations on the utilization of mineral resources, plays an important role in the inhibitory effect of environmental regulations on the utilization of mineral resources, and enhances the enforcement of environmental regulations.

According to the research results of the environmental impact of the utilization of mineral resources, the following corresponding policy suggestions are given in this paper:

First, government departments should encourage technological innovation in the whole industrial chain of mineral resources, especially the suppression of pollution and the conservation of mineral resources, so as to improve the utilization rate of mineral resources and reduce the pollution caused by the exploitation and utilization of mineral 
resources. Relevant departments should strengthen government incentives and monitoring to improve the cleanliness of the utilization of mineral resources.

In addition, the government should enhance the degree of environmental regulation implementation, which can not only curb the high pollution problem of the utilization of mineral resources, but also reduce the degree of mineral resources exploitation from the source, improve the utilization rate of mineral resources in China and alleviate the dilemma of insufficient resource supply in China.

Finally, relevant government departments should pay attention to the industrial structure, technological progress and the role of government management in the industrial chain of mineral resources. Promoting the upgrading of industrial structure, technological progress and strengthening government management are the key ways to improve the cleanness and utilization of mineral resources.

Author Contributions: Conceptualization, W.Z.; Data curation, W.Z. and K.Z.; Formal analysis, K.Z.; Funding acquisition, D.X.; Investigation, K.Z. and Z.L.; Methodology, K.Z.; Project administration, D.X.; Resources, Z.L.; Software, K.Z.; Supervision, D.X.; Validation, K.Z.; Visualization, K.Z.; Writingoriginal draft preparation, W.Z.; Writing - review and editing, W.Z., K.Z. and J.G. All authors have read and agreed to the published version of the manuscript.

Funding: This research was funded by the Natural Science Foundation of China (No. 72074197, No. 71991482, No. 71991480), the Open Fund Project of Hubei Provincial Research Base for Regional Innovation Capacity Monitoring and Analysis Soft Science (No. HBQY2020z10) and the Major Research Projects of Guangxi Department of Natural Resources in 2019 (Sub-bid C) (No. GXZC2019G3-25122-GXGL-C).

Institutional Review Board Statement: Not applicable.

Informed Consent Statement: Not applicable.

Data Availability Statement: The data comes from the "China Environmental Statistical Yearbook", "China Statistical Yearbook" and the EPS data platform.

Conflicts of Interest: The authors declare no conflict of interest.

\section{References}

1. Majeed, A.; Wang, L.; Zhang, X.; Muniba; Kirikkaleli, D. Modeling the dynamic links among natural resources, economic globalization, disaggregated energy consumption, and environmental quality: Fresh evidence from GCC economies. Resour. Policy 2021, 73, 102204. [CrossRef]

2. Tingru, Y.; Wenling, L. Does air pollution affect public health and health inequality? Empirical evidence from China. J. Clean. Prod. 2018, 203, 43-52.

3. Wang, C.; Guan, D.; Cai, W. Grand Challenges Cannot Be Treated in Isolation. One Earth 2019, 1, 24-26. [CrossRef]

4. Li, D.; Zhao, Y.; Li, L. Change of environmental efficiency and environmental productivity of coal cities: Based on panel data of 11 cities in Shanxi province. J. Nat. Resour. 2021, 36, 618-633.

5. Giurco, D.; Cooper, C. Mining and sustainability: Asking the right questions. Miner. Eng. 2012, 29, 3-12. [CrossRef]

6. Wang, C.; Pu, C. Benefit-share machanism on the process of energy mineral resources exploitation in Xinjiang. Econ. Geogr. 2011, 31, 1152-1156.

7. Bebbington, A.J.; Bury, J.T. Institutional challenges for mining and sustainability in Peru. Proc. Natl. Acad. Sci. USA 2009, 106, 17296-17301. [CrossRef]

8. Kelly, R.; Pecl, G.T.; Fleming, A. Social licence in the marine sector: A review of understanding and application. Mar. Policy 2017, 81, 21-28. [CrossRef]

9. Pokhrel, L.R.; Dubey, B. Global scenarios of metal mining, environmental repercussions, public policies, and sustainability: A review. Crit. Rev. Environ. Sci. Technol. 2013, 43, 2352-2388. [CrossRef]

10. Lange, I.; Redlinger, M. Effects of stricter environmental regulations on resource development. J. Environ. Econ. Manag. 2019, 96, 60-87. [CrossRef]

11. Zhu, X.; Fan, Y.; Zhong, M. The Evaluation of Rare Metal Minerals Tariffs Alternative Policy and Its Effect on the Pricing Power. J. Int. Trade 2016, 12, 107-118.

12. Tao, F.; Zhao, J.; Zhou, H. Does Environmental Regulation Improve the Quantity and Quality of Green Innovation: Evidence from the Target Responsibility System of Environmental Protection. China Ind. Econ. 2021, 2, 136-154.

13. Li, Q.; Xiao, Z. Heterogeneous Environmental Regulation Tools and Green Innovation Incentives: Evidence from Green Patents of Listed Companies. Econ. Res. J. 2020, 55, 192-208. 
14. Wang, L.; Wang, H.; Dong, Z. Policy Conditions for Compatibility between Economic Growth and Environmental Quality: A Test of Policy Bias Effects from the Perspective of the Direction of Environmental Technological Progress. Manag. World 2020, $36,39-60$.

15. Chen, B.; Li, T. Do Fiscal Decentralization and Environmental Regulation Promote Green Technology Innovation in China? Stat. Res. 2020, 37, 27-39.

16. Kong, R.; Xue, F.; Wang, J.; Zhai, H.; Zhao, L. Research on mineral resources and environment of salt lakes in Qinghai Province based on system dynamics theory. Resour. Policy 2017, 52, 19-28. [CrossRef]

17. Xing, L.; Xue, M.; Hu, M. Dynamic simulation and assessment of the coupling coordination degree of the economy-resourceenvironment system: Case of Wuhan City in China. J. Environ. Manag. 2019, 230, 474-487. [CrossRef]

18. Li, L.; Lei, Y.; Wu, S.; He, C.; Yan, D. Study on the coordinated development of economy, environment and resource in coal-based areas in Shanxi Province in China: Based on the multi-objective optimization model. Resour. Policy 2018, 55, 80-86. [CrossRef]

19. Cãpãpînã, C.; Lazãr, G. The study of the air pollution by a surface mining exploitation from romania. J. Univ. Chem. Technol. Metall. 2008, 43, 245-250.

20. Chikkatur, A.P.; Sagar, A.D.; Sankar, T.L. Sustainable development of the Indian coal sector. Energy 2009, 34, 942-953. [CrossRef]

21. Pagiola, S.; Arcenas, A.; Platais, G. Can payments for environmental services help reduce poverty? An exploration of the issues and the evidence to date from Latin America. World Dev. 2005, 33, 237-253. [CrossRef]

22. Andreoni, J.; Levinson, A. The simple analytics of the environmental Kuznets curve. J. Public Econ. 2001, 80, 269-286. [CrossRef]

23. Jia, S.; Huang, J.; Zhong, M. Emergy analysis of the development of nonferrous metals in jiangxi province under the background of ecological civilization construction. Resour. Environ. Yangtze Basin 2017, 26, 1378-1387.

24. Kesler, S.E.; Simon, A.C.; Simon, A.F. Mineral Resources, Economics and the Environment; Cambridge University Press: Cambridge, UK, 2015.

25. Kang, M.; Stam, A. PAHAP: A pairwise aggregated hierarchical analysis of ratio-scale preferences. Decis. Sci. 2010, 25, 607-624. [CrossRef]

26. Sanmiquel, L.; Bascompta, M.; Vintró, C.; Yubero, T. Subsidence management system for underground mining. Minerals 2018, 8, 243. [CrossRef]

27. Väizene, V.; Valgma, I.; Karu, V.; Orru, M. Environmental impact of oil shale mining. Environ. Earth Sci. 2016, 75, 1201. [CrossRef]

28. Yang, D.; Qu, S.; Li, P. Analysis on environmental impact of rare mineral mining and utilization. China Popul. Resour. Environ. 2014, 24, 230-234.

29. Chang, Y.C.; Wang, C.; Khan, M.I.; Wang, N. The legal system for environmental protection during exploration and exploitation of marine mineral resources in China. Resour. Policy 2020, 67, 101670. [CrossRef]

30. Omotehinse, A.O.; Ako, B.D. The environmental implications of the exploration and exploitation of solid minerals in Nigeria with a special focus on Tin in Jos and Coal in Enugu. J. Sustain. Min. 2019, 18, 18-24. [CrossRef]

31. Kaniki, A.T.; Tumba, K. Management of mineral processing tailings and metallurgical slags of the Congolese copperbelt: Environmental stakes and perspectives. J. Clean. Prod. 2019, 210, 1406-1413. [CrossRef]

32. Kaikkonen, L.; Venesjärvi, R.; Nygård, H.; Kuikka, S. Assessing the impacts of seabed mineral extraction in the deep sea and coastal marine environments: Current methods and recommendations for environmental risk assessment. Mar. Pollut. Bull. 2018, 135, 1183-1197. [CrossRef]

33. Wang, F.; Guo, X. Effects of environmental regulation intensity on green technological innovation of resource-based industries. China Popul. Resour. Environ. 2015, 25, 143-146.

34. Wang, X.; Ge, J.; Li, J.; Han, A. Market impacts of environmental regulations on the production of rare earths: A computable general equilibrium analysis for China. J. Clean. Prod. 2017, 154, 614-620. [CrossRef]

35. Gao, W.; Cheng, J.; Zhang, J. The influence of heterogeneous environmental regulation on the green development of mining industry. China Popul. Resour. Environ. 2018, 28, 150-161.

36. Chen, J.; Cheng, J. Environmental impacts caused by the development and utilization of mineral resources in China. China Popul. Resour. Environ. 2015, 25, 111-119.

37. Qu, W. Environmental Regulation, Spatial Spillover and Regional Ecological Efficiency: An Empirical Analysis of Douban Panel Model based on Space. J. Beijing Inst. Technol. 2018, 20, 27-33.

38. Elhorst, J.P. Spatial Econometrics from Cross-Sectional Data to Spatial Panels; Springer: Berlin/Heidelberg, Germany, $2014 ;$ pp. 37-60.

39. Jin, G.; Shen, K. Polluting thy neighbor or benefiting thy neighbor: Enforcement interaction of environmental regulation and productivity growth of chinese cities. Manag. World 2018, 34, 43-55.

40. Dong, Z.; Wang, H. Local-Neighborhood Effect of Green Technology of Environmental Regulation. China Ind. Econ. 2019, 1, 100-118.

41. Zhu, P.; Zhang, Z.; Jiang, G. Empirical study of the relationship between FDI and environmental regulation:an intergovernmental competition perspective. Econ. Res. J. 2011, 46, 133-145.

42. Zhang, K.; Xu, D.; Li, S. The impact of environmental regulation on environmental pollution in China: An empirical study based on the synergistic effect of industrial agglomeration. Environ. Sci. Pollut. Res. 2019, 26, 25775-25788. [CrossRef]

43. Zhang, K.; Xu, D.; Li, S.; Zhou, N.; Xiong, J. Has China's pilot emissions trading scheme influenced the carbon intensity of output? Int. J. Environ. Res. Public Health 2019, 16, 1854. [CrossRef] [PubMed] 